\title{
GPS受信機の時刻同期信号を用いた 海上位置情報通信システムの実験的検討
}

吉田 将司 ${ }^{*}$. 北條晴正 ${ }^{* *}$. 樊 春明*** 安田 明生 ${ }^{* * * *}$

\section{Experimental Evaluation of Maritime Position Communication System Synchronized by PPS Signal of a GPS Receiver}

\author{
Masashi YOSHIDA, Harumasa HOJO, Fan CHUNMING and Akio YASUDA
}

\begin{abstract}
The authors proposed an extremely weak power radio DS-SS communication system that used the 1PPS signal of the GPS receiver for the code synchronization of the marine location information system in the emergency. One second data frame, triggered by PPS signal every second, is comprised of spread data with a phase detection sequence at the top. First, we measured the reception power, BER and detection probability when the sending point was fixed. We obtained better BER than $10^{-3}$ at $80 \mathrm{~m}$. Next, we measured them when the ship has the transmitter. The result proved that the present method is effective, although the values were degraded comparing to the case of fixed transmitter.
\end{abstract}

Keywords :GPS, PPS signal, Low power radio, Spread spectrum Communication キーワード : GPS, PPS 信号, 微弱電波, スペクトラム拡散通信

\section{1. はじめに}

近年海上でのレジャー人口の増加とともに、通信 設備の乏しい小型船舶での海中転落や漂流事故が増 加している。これらの事故は発生の確認が遅く、救 助も遅れるため死亡率が高い。このため海中転落者 や漂流者の救難を目的とした小型の位置情報通信シ ステムが求められている(1)。GPSによって取得した 位置情報を送信するための方法として通信衛星や GPS 機能付携帯電話、特定小電力無線など様々な方 法が提案されている ${ }^{(2) ~(6)}$ が、携帯電話は東京湾など 一部の沿岸を除くと海上では通話圈外である可能性 が高い。特定小電力無線は技術適合認証されたもの でなければ使用できず、搬送波周波数や変調方式が 定められている。ISM バンド（2.4GHz 帯）は特定小 電力無線より自由度は高いものの、技術適合認証が
必要であり、自由なシステム構築には制限がある。

一方、微弱電波機器は受信電界強度に関する制限 があるものの周波数、変調方式等の選択が自由であ ることや無線局の免許なしで使用できる利点がある。 ただし通信距離は一般的に数 $10 \mathrm{~m}$ 以内と短く ${ }^{(7)} 、 キ$ 一レスエントリなど接点制御には利用されるものの 通信システムの構築にはほとんど使用されていない。 スペクトラム拡散 (Spread Spectrum, DS-SS) 方式を 採用し処理利得により通信距離を伸ばす方法もある が、まず受信側がリアルタイムで同期していなけれ ばならない。また相関及び同期追跡はディジタル回 路内において高速で複雑、高度な算術演算を行う必 要があり、そのためには大規模なデバイスが必要で ある。さらに受信電力が微弱であれば搬送波同期や 拡散符号同期が困難であり、その報告例は僅かであ $ろ^{(8)}$ 。

\footnotetext{
* 学生会員 東京海洋大学大学院（广 135-8533 東京都江東区越中島 2-1-6） masashi@denshi.e.kaiyodai.ac.jp

** 正会員 東京海洋大学客員教授

*** 正会員 東京海洋大学 海洋生産学科（广 108-8477 東京都港区港南 4-5-7）

**** 正会員 東京海洋大学 情報通信工学研究室（广135-8533 東京都江東区越中島 $2 \cdot 1 \cdot 6 ）$
} 


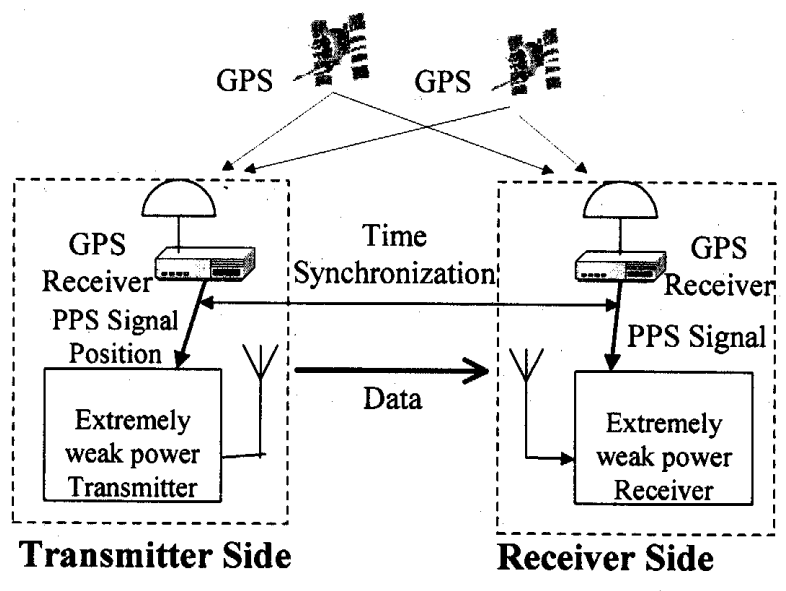

Fig.1 The system configuration

そこで筆者らは通常測位のために DS-SS 方式で同 期捕捉、同期追跡を行っている GPS を利用し、GPS 受信機から出力される時刻同期信号 (Pulse Per Second 信号、以下PPS 信号) を利用して送受信機の チップ同期を行い、簡易な構成による DS-SS 方式を 提案し、通信距離の拡大やビット誤り率特性（Bit Error Rate、BER 特性) の改善が可能となることを 報告している( ${ }^{(9)}$ 。この位置情報通信システムは、乗 船者が船舶から転落した直後や漂流者から救助者・ 救助船舶が確認できるものの、救助者側からは確認 できない場合など、 $1 \mathrm{k} \mathrm{m}$ 程度までの通信距離を想定 している。

本研究では、まず GPS 受信機から出力される PPS 信号を利用した微弱電波 DS-SS 通信方式について説 明し、同期方法の改善について述べる。次に実際に 回路を FPGA (Field Programmable Gate Array)に実 装し、微弱電波機器を使用した通信実験により、提 案方式の有効性を検証した。次に提案するシステム の実用化に向けた実験として屋外で BER 特性と受信 電力特性を測定した。さらに測定した值と理論值と を比較、評価した。最後に評価の結果、この微弱電 波 DS-SS 通信方式が有効であり、提案するシステム が充分構築可能であることを示した。

\section{2. システムの概要と構成} 2.1 システムの概要

Fig. 1 にPPS 信号をチップ同期に利用した微弱電 波 DS-SS 通信システムの構成概念図を示す。送信機 と受信機は、ともにGPS 受信機と信号処理回路、通 信用の微弱電波通信機の RF 部で構成される。使用す る $\mathrm{RF}$ 部の変調方式は自由である。まず送信機には GPS 受信機から毎秒位置情報と PPS 信号が入力され、

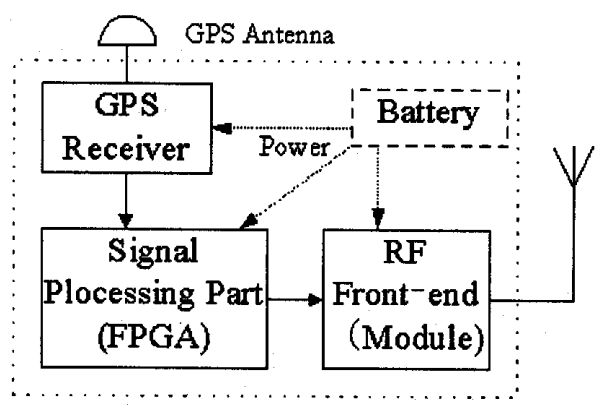

(a) Transm itter

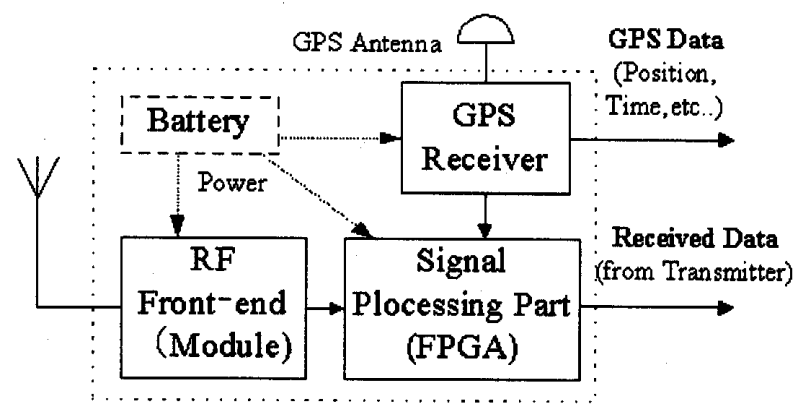

(b) Receiver

Fig.2 Configuration of transmitter (a) and receiver (b)

PPS 信号をトリガとして拡散符号が出力される。送 信データは拡散符号によりスペクトラム拡散されて $\mathrm{RF}$ 部に出力、搬送波を変調してアンテナから送信さ れる。一方受信機でも、GPS 受信機から PPS 信号が 送信機と同じタイミングで入力されるため、DS-SS で必要となるチップ同期を容易にとることができる。 受信側のRF部で一次復調された受信信号とPPS信号 をトリガとして生成した拡散符号とで逆拡散が行わ れ、データを取り出すことができる。

同期信号として使用されるPPS 信号の精度につい ては、GPS 時刻が周波数標準による測定により UTC との差が 10ns 以内に維持されている(10)。また一般 的な GPS 受信機から出力される PPS 信号は、バイア スを校正すれば $50 \mathrm{~ns}$ で、校正しない場合も 150ns の精度である(11)。

\section{2 符号位相制御によるチップ同期の改善}

Fig. 2(a)、（b）にそれぞれ送信機、受信機の構成を 示す。前述の同期方法の場合、送信機と受信機が同 時刻に拡散符号を送出して拡散及び逆拡散を行うた め、伝搬時間が拡散符号の 1 チップ分の周期よりも 長くなると、チップ同期がとれず、通信可能な距離 と情報伝送速度は拡散符号のチップレートによって 制限されていた。そこで今回は、伝搬距離の変化に 関係なく同期を維持させるため、同期方法を改良し 


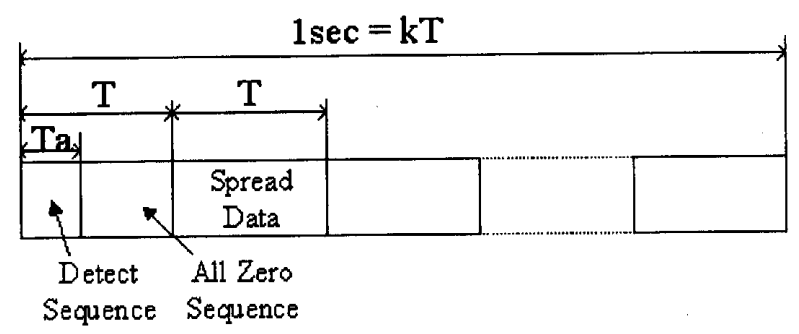

(a) $\mathrm{T}>\mathrm{Ta}$

\begin{tabular}{|c|c|c|}
\hline \multicolumn{3}{|c|}{$1 \mathrm{sec}=\mathrm{kT}$} \\
\hline $\mathrm{iT}$ & & \\
\hline $\mathrm{Ta}$ & $\mathrm{T}$ & \\
\hline $\begin{array}{c}\text { Detect } \\
\text { Sequence }\end{array}$ & $\begin{array}{c}\text { Spread } \\
\text { Data }\end{array}$ & \\
\hline
\end{tabular}

(b) $\mathrm{T} \leqq \mathrm{Ta}$

Fig. 3 Structure of the transmission data frame $(\mathrm{T}>\mathrm{Ta}$ (a), $\mathrm{T} \leqq \mathrm{Ta}(\mathrm{b}))$

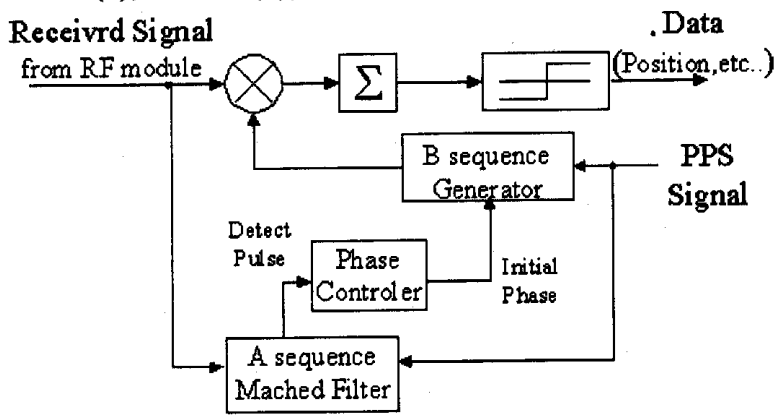

Fig.4 Configuration of Signal Processing of a Receiver

た。送信データ（以下、情報系列）をスペクトラム 拡散する拡散符号（以下、情報拡散系列）に加え、 情報拡散系列の符号位相を検出するため新たに別の 拡散符号（以下、位相検出系列）を挿入することに より拡散符号の初期位相を制御させる方法である。 前項では送受信システムの概要を述べたが、ここで は符号位相による制御方法について述べる。

1 秒毎の送信フレームはFig. 3で示すように位相 検出系列と、情報拡散系列で拡散された情報系列で 構成されている。送信機にPPS 信号が入力されると PPS 信号をトリガとして位相検出系列と情報拡散系 列が生成される。ここで位相検出系列を系列A、情報 拡散系列を系列 $B$ とおく。系列 $A$ は回路構成の便宜上、 Tのi倍の長さに設定する(iは正の整数)。ただし、 Fig. 3 (a)のようにT>Taの場合は、Tとの差分 $(n-m)$ を0系列で埋め、系列Bと同じ長さ（i=1）とする。こ のとき、系列 $A$ が挿入されると、1秒間に伝送する情

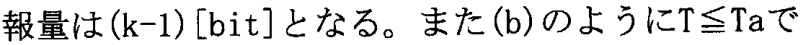
あればT $=\mathrm{Ta}$ の場合を除き、長さがiTとなるように 超過分を切り捨てる。長さiTの系列Aが挿入されるた
め、1秒間に伝送する情報量は $(k-i)[b i t]$ となる。 これは iが0であれば位相検出系列を使用しない 状態であること、逆にiが増加するほど伝送可能な情 報量は低下することを意味する。なお、誤り訂正な どは本論文では触れず、後述の実験においても誤り 訂正符号化は行っていない。

Fig. 4 に受信機の信号処理部の構成を示寸。伝搬 遅延時間を受信機で生成される拡散符号の符号位相 として検出すれば、その初期位相を修正して同期を 確立させることができる。位相検出はマッチドフィ ルタと閾值判定部で構成され、相関值が閾値を超え た場合、系列 $\mathrm{A}$ を検出したものと判断しパルスを出 力する。位相制御部では出力されたパルスを利用し て初期位相を修正し、系列 B を送出する。同期後も その検出は毎秒行われ、PPS 信号が入力されたとき に符号位相を制御するだけで信号を追尾できる利点 がある。さらに位相検出系列をプリアンブルとして 用いればフレーム同期も取れるため、情報の復号の 高速化が期待できる。

さらに、このシステムはチップレートが高速化で きれば、簡単な測距が可能である。例えばチップレ ートが 3MHz 以上であれば、PPS 信号からの遅延時間 を計測することにより 100m オーダでの測距が可能 である。もし位置が不明でも、距離情報を得ること で捜索範囲を狭めることができる利点がある。

\section{3. 通信実験とその評価 3.1 実験システムの構成}

本論文では、系列 A のコード長をそれぞれ 127bit $\left(A_{127}\right) 、 1023 b i t\left(A_{1023}\right)$ とし、系列 B のコード 長を $1023 \mathrm{bit}\left(\mathrm{B}_{1023}\right)$ に固定、位相検出系列を用いずに 系列 $\mathrm{B}$ のみで相関をとる方法 $\left(\mathrm{N}_{1023}\right)$ とスペクトラ 厶拡散を行わずチップレートと同じ伝送速度で通信 を行う方法 (N-SP) とで比較した。Table1にパラメ 一タの一覧を示す。 $A_{127} 、 A_{1023}$ と $B_{1023}$ の相互相関を計 算し、その中でそれぞれ最も良い組み合わせを選択 して使用した。ただし $\mathrm{N}_{1023}$ は $\mathrm{A}_{1023}$ と同様のタップ位 置とした。FPGA ボードと微弱無線モジュールで構成 される送受信機と PPS 出力のある GPS 受信機を使用 した。次に、使用した微弱無線モジュールの諸元を Table2 に示す。微弱無線モジュールには BER 特性の 良い BPSK (Bi-Phase Shift Keying)や、高い受信感 度、通信速度が速いものが最適であるが、それらの 条件を全て満たすものが入手できないため、入手が 容易で通信速度が速い包絡線検波 ASK (Amplitude Shift Keying) モジュールを使用した。ただし、本実 
Table 1 Parameter of the experiment

\begin{tabular}{|l|c|c|c|c|}
\hline & $\mathrm{A} 1023$ & $\mathrm{~A} 127$ & $\mathrm{~N} 1023$ & N-SP \\
\hline Chipping Rate[bps] & $20.46 \mathrm{k}$ & $20.46 \mathrm{k}$ & $20.46 \mathrm{k}$ & - \\
\hline Data Rate[bps] & 20 & 20 & 20 & $20.46 \mathrm{k}$ \\
\hline Sequence A[bit] & 1023 & 127 & - & - \\
\hline
\end{tabular}

Table 2 Specification of the RF module

\begin{tabular}{|c|c|}
\hline Carrier Frequency & $303.78 \mathrm{MHz}$ \\
\hline Transmitting Power & $-43.5 \mathrm{dBm}$ \\
\hline Modulation & Asynchronous ASK \\
\hline IF Rate & $20.46 \mathrm{kbps}$ \\
\hline
\end{tabular}

験での RF 部への伝送速度は20.46kbps と低速であり、 本実験では測距性能については評価していない。

\section{2 室内における実証実験}

提案した通信システムを評価するために、まず微 弱電波 DS-SS 方式の有效性を検証した。また提案す るシステムの評価だけでなく、新しい同期方法の導 入効果も検証した。

Fig. 5 に実験構成を示す。送受信機間距離を $4 \mathrm{~m}$ と 設定し、 $A_{1023 、} \mathrm{~N}_{1023} 、 \mathrm{~N}-\mathrm{SP}$ の各条件における BER を 測定した。測定は 2 回に分けて実施し、BER 特性は 2 回の測定における送信データ数と誤りの合計值で評 価する。送信アンテナ及び受信アンテナは共に無指 向性のロッドアンテナ $(\mathrm{Gain}=-5.5 \mathrm{~dB})$ を使用し、高 さは共に $1.0 \mathrm{~m}$ とした。実験で使用する微弱無線そ ジュールの送信出力は、式(1)より求めることができ る。

$E=\frac{7 \sqrt{P t}}{d} \quad[\mathrm{~V} / \mathrm{m}]$

ただしEは電界強度、 $\mathrm{d}$ は距離、Ptは送信電力であ る。この式 (1)に電波法の受信電界強度の制限值であ るE $=500 \mu \mathrm{V} / \mathrm{m} 、 \mathrm{~d}=3 \mathrm{~m}$ 代入するとPt は約 $-43.4 \mathrm{dBm}$ となる。そこで本実験ではそれより低い值とした。 BERは、受信機側FPGAにBER測定用回路を加え、その 結果をユニバーサルカウンタで計測して求めた。ま た、距離特性を推定するために、受信側アンテナ一 微弱無線モジュール間に $10 \mathrm{~dB}$ 及び20dBの減衰器を挿 入し、受信電力を低下させて同様にBERを測定した。 $10 \mathrm{~dB}$ 及び $20 \mathrm{~dB}$ の減衰器を挿入した場合のBER特性は、 実際よりもそれぞれ約3.3倍と10倍の距離における

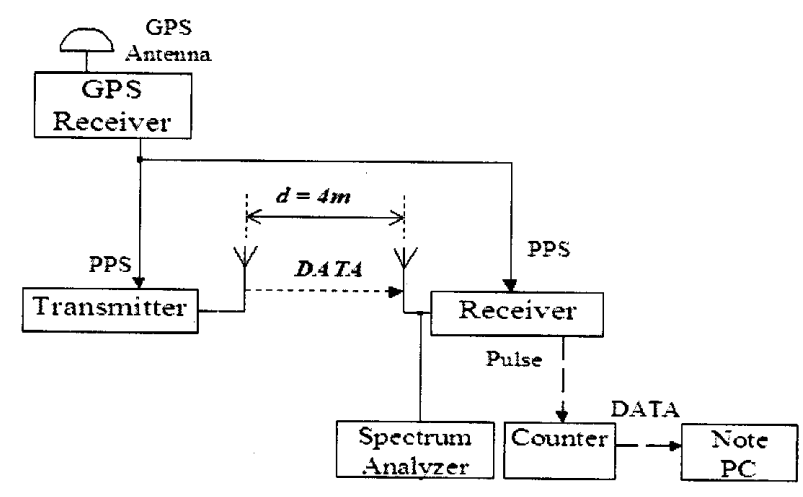

Fig.5 Configuration of the indoor experiment

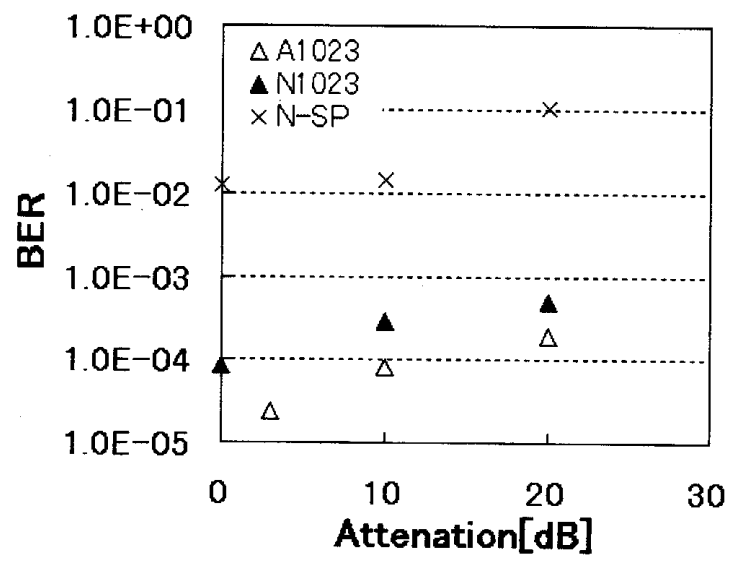

Fig.6 The BER characteristic of the indoor experiment

結果であると推定できる。本実験の場合は約 $13.2 \mathrm{~m}$ と $40 \mathrm{~m}$ に相当する。

Fig. 6にBER特性の測定結果を示す。 $A_{1023}$ は2回の測 定で誤りを生じなかったため、3dBの減衰器を挿入し た結果を示している。この図で示されるように、RF 部と信号処理部の間を同じ速度で信号伝送した場合、 DS-SSの処理利得による特性改善の効果が明らかで ある。 $\mathrm{A}_{1023}$ は $\mathrm{N}_{1023}$ より優れたBER特性を示しており、 新しい同期方法の導入効果も示すことができた。ま た、20dBの減衰器を挿入した場合のBER特性は、N-SP は $10^{-1}$ 程度と急激に劣化した。DS-SS方式 $\left(\mathrm{N}_{1023} 、 \mathrm{~A}_{1023}\right)$ でのBERも劣化したが、それでもN-SPと比べて約 100 倍優れており、提案方式の有効性を示している。

この結果から、本方式を利用すれば従来の方式よ り通信容量が低下するものの、高い通信品質でさら に遠距離の通信が可能になることを示した。

\section{3 屋外実験結果}

次に、システム実現のための実証実験の第一段階 として屋外における通信実験を行った。Fig.7に実験 の構成を、Fig.8に実験の配置図をそれぞれ示す。実 


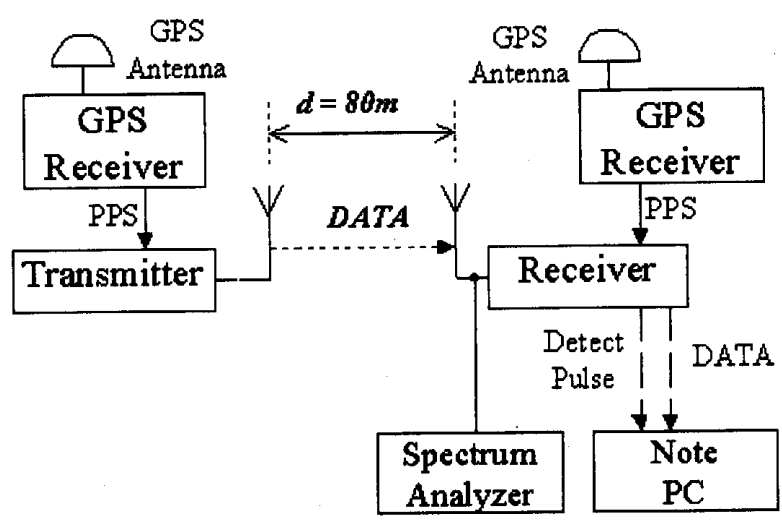

Fig.7 Configuration of the outdoor experiment

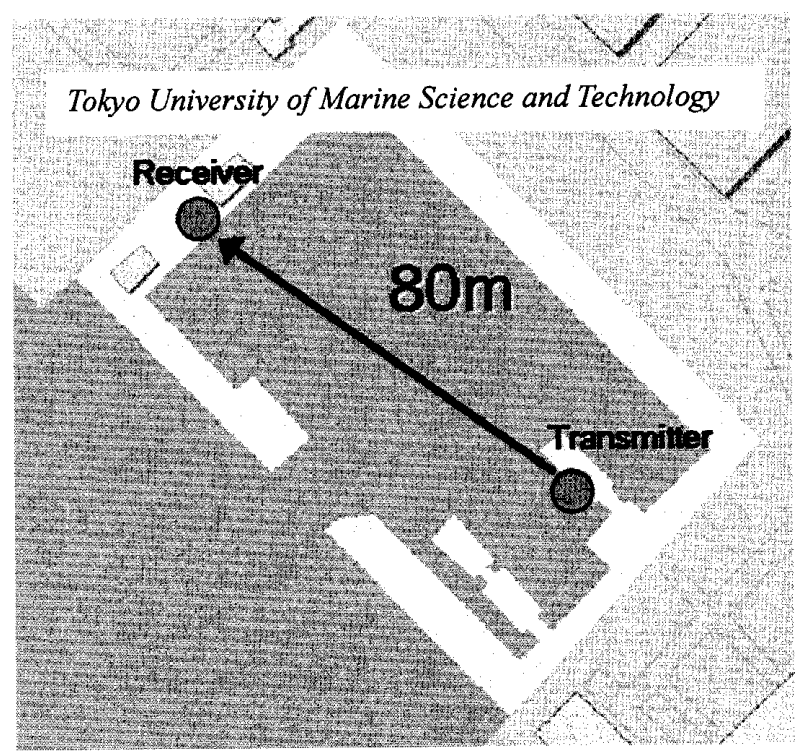

Fig.8 Geometrical configuration of the experimental units

験場所は東京海洋大学越中島キャンパス内の小型船 係留施設で、送受信機間距離 $\mathrm{d}$ はそのほぼ両端の約 $80 \mathrm{~m}$ に固定した。また海面近くから送信が行われる 使用状況を想定し、送信アンテナ高さを $0.5 \mathrm{~m}$ と低く

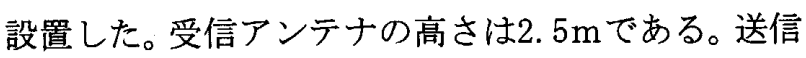
データには511bitのPN符号を用いた。微弱電波は電 波法で受信アンテナに関する規制はなく、微弱無線 モジュールの受信感度を補うことができる。そこで 受信側のアンテナに指向性のあるログペリオディッ クアンテナ (Log-Periodic antenna)を使用した。指 向性を持つアンテナの場合、全方位の同時探索は難 しいが、アンテナを旋回させること等で対応可能で ある。また一旦信号を捕捉した場合は指向性を持つ アンテナで信号を追尾する方が有利と考えられる。 またFPGAからのディジタル信号出力をPCで直接取得 するため、ディジタルI/0カードをノートPCに挿入し て使用した。受信データ、相関值フラグ（閾値未満 の場合に 1 )、位相検出フラグ (位相検出系列が検出
Table 3 Results of measurement-1

\begin{tabular}{|l|c|c|c|c|}
\hline & BER & $\begin{array}{c}\text { Detect } \\
\text { Rate }\end{array}$ & $\begin{array}{c}\mathrm{Eb} / \mathrm{No} \\
{[\mathrm{dB}]}\end{array}$ & $\begin{array}{c}\text { Pr } \\
{[\mathrm{dBm}]}\end{array}$ \\
\hline $\mathrm{A} 1023$ & $5.60^{*} 10^{-4}$ & 1.000 & 14.5 & -93.3 \\
\hline $\mathrm{A} 127$ & $1.87^{*} 10^{-3}$ & 0.988 & 13.7 & -94.0 \\
\hline $\mathrm{N} 1023$ & $2.70^{*} 10^{-3}$ & - & 13.4 & -92.4 \\
\hline
\end{tabular}

された場合に 1）を毎秒取得した。実験は 2 日に分 け1回の測定はそれぞれ20分以上行った。

Table3に $A_{1023} 、 A_{127}$ 及び $N_{1023}$ の場合におけるBER特性 と位相検出系列の検出率を示す。この值は 2 回行っ た測定の合計值である。ただし受信電力のみ 2 回の 平均值である。 $\mathrm{A}_{1023}$ が他の場合と比較して最も各特 性で良い結果であった。また $A_{127}$ のBERも $\mathrm{N}_{1023}$ より $69 \%$ 低下したことから、系列Aの挿入によりBER特性が改 善されることがわかる。次に検出率の測定では、測 定時間中において $A_{1023}$ は全て検出され、 $A_{127}$ は僅かに 不検出が発生した。この結果から系列Aの不検出の要 因は、系列Aの処理利得の影響が大きく、ハードウェ アの容量に制約がなければ、コード長の長い系列A を使用して検出率を改善することができると考えら れる。Table3中の 1 bitあたりのエネルギ密度でシス テム全体のSN比を表す $\mathrm{Eb} / \mathrm{No}$ 特性は、測定で得られた BERを利用して、ASKにおける理論值を求めたもので ある。ただし実験に使用した無線モジュールはHレベ ル(データが1) とLレベル(データが0)の振幅比が約 40倍ある。また包絡線検波であるため非同期であり、 $\mathrm{Eb} / \mathrm{No}$ とERの関係式は式(2)のように表すことがで きる。

$B E R=\frac{1}{2} \exp \left(-\frac{0.96^{*} E b}{4 N o}\right)$

式(2) 中の括弧の中は、2 值ディジタル変調におけ る復調出力 $\mathrm{E}_{\mathrm{d}}$ を求める式 ${ }^{(12)}$ 、

$E_{d}=\int_{-\infty}^{+\infty}\left[p_{1}(t)-p_{2}(t)\right]^{2} d t$

から計算した結果から求めることができる。ただし、 $\mathrm{p}_{1}(\mathrm{t})$ 及び $\mathrm{p}_{2}(\mathrm{t})$ は、Hレベル時の信号の振幅を $\mathrm{A}_{\mathrm{c}}$ 、搬 送波周波数を $\omega$ とすると振幅比から近似的に、

$p_{1}(t)=A_{c} \cos \omega t$

$p_{2}(t)=\frac{1}{40} A_{c} \cos \omega t$

とおくことができる。式(2) は自由空間環境で熱雑音 
のみを考慮する理論式である。本実験の場合、実際 には見通し環境で且つ直接波と反射波が存在する仲 上ーライスフェージング環境下であると考えられる。 その場合の理論式は、

$$
B E R=\frac{1}{2} \frac{1}{1+\frac{0.96 E b}{4 N o}} \exp \left(-\frac{1}{1+\zeta}\left(\frac{1+\zeta}{\frac{0.96 E b}{4 N o}}\right)\right.
$$

と求めることができる ${ }^{(13)}$ 。ここでらは直接波と反射 波の電力比であり、らが大きければ式(2)に近くなり、 逆にら=0の場合は見通し外のレイリーフェージング 環境となる。

本実験においては直接波と反射波の電力比を測定 できず、らの算出が困難であるため、式(2)から計算 された $\mathrm{Eb} / \mathrm{No}$ で比較した。 $\mathrm{A}_{127}$ は $\mathrm{N}_{1023}$ に比べて $0.3 \mathrm{~dB}$ 、 $\mathrm{A}_{1023}$ の場合は $1.1 \mathrm{~dB}$ 優れており、式(6)で求めた場合 はさらに差があると考えられる。また、もし同じ非 同期検波でも、DBPSK (Deferential Bi-Phase Shift Keying)の微弱無線モジュールを使用して実験を行 い同じEb/No特性が得られるとすれば、DBPSKの自 由空間における理論式は、

$$
B E R=\frac{1}{2} \exp \left(-\frac{E b}{N o}\right)
$$

であることから、大幅なBER特性の向上が期待できる。 また受信電力は、自由空間伝搬における理論值 $-93.7[\mathrm{dBm}]$ と、反射損失も含めた理論值 $-107.7[\mathrm{dBm}]$ から比較すると、いずれの場合も自由空間伝搬にお ける理論值に近い值を示し、反射損失を加えた場合 とは大きく異なる結果となった。

\section{4 小型船を用いた距離特性測定}

最後に、実証実験の第二段階として小型船を用い て水上で同様の測定を行った。まず 3.3 と同じ通信 距離である $80 \mathrm{~m}$ 付近で船を停止させ、 $\mathrm{A}_{1023}$ の条件で データ伝送実験と受信電力測定を行った。次に距離 を徐々に伸ばし、約 $180 \mathrm{~m}$ 付近まで同様の測定を繰り 返した。また、比較のため $\mathrm{N}_{1023}$ に変更して $55 \mathrm{~m} \sim 80 \mathrm{~m}$ の距離で測定を行った。Fig. 9 は実験時における送 信側の構成、Fig. 10 は受信側から見た送信側の様子 を示す。Fig. 9 のように、送信側のアンテナ高は 3.3 と比べて高く $1 \mathrm{~m}$ 程度、また受信側は $2.5 \mathrm{~m}$ と変化し

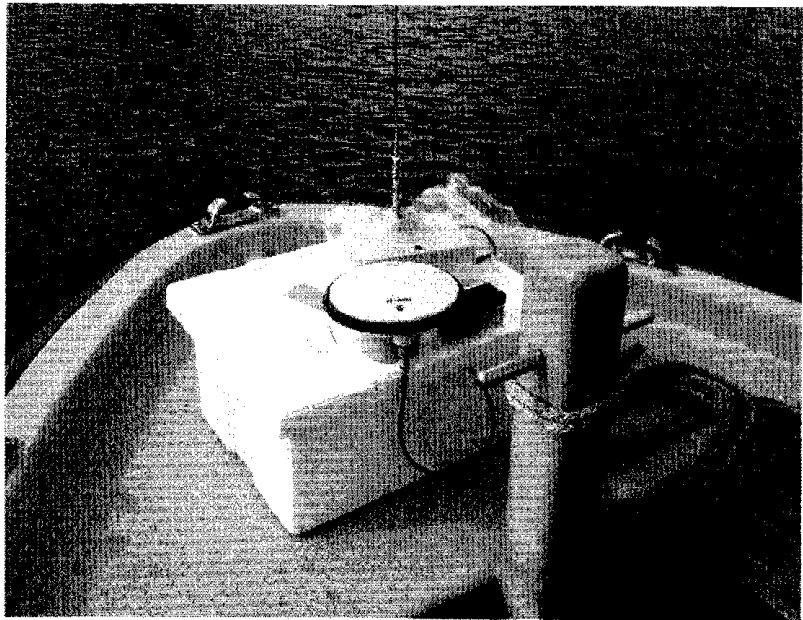

Fig.9 The state of the transmitter on the ship

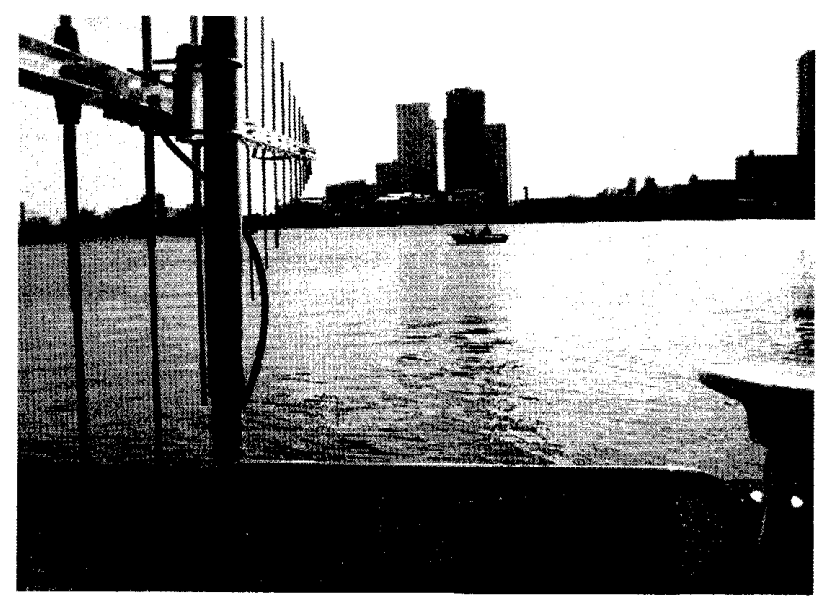

Fig.10 The state of the communication experiment which used a boat

ていない。ただし測定中、送信側は風や川の流れの 影響などで完全に停止できず、10２0m程度距離が 変化していた。

Table4 に $80 \mathrm{~m}$ 付近で取得した測定結果を示す。 Table3 と比較して BER が劣化し、Eb/Noが減少して いる。しかしその差は $1.1 \mathrm{~dB}$ と 3.3 での結果と変わ らなかったことから提案方式の有効性が確認できた。 また検出確率は 50\%以下に低下した。ただし、受信 電力は $\mathrm{N}_{1023}$ の場合の方が高いにもかかわらず、 $\mathrm{A}_{1023}$ の BER 特性の方が優れておう、今回導入した同期方 法が有効であることをこの実験結果からも示すこと ができたと考えられる。

Fig. 11 に距離と受信電力の関係を示す。自由空間 伝搬における損失 $\mathrm{L}_{\mathrm{F}}$ は、

$L_{F}=20 \log (f d)-27.56-G a \quad[\mathrm{~dB}]$

と求められる(14)。ここで $\mathrm{f}$ は搬送波周波数 $[\mathrm{MHz}] 、 \mathrm{~d}$ は距離 $[\mathrm{m}] 、 \mathrm{Ga}$ はアンテナ利得である。一方 2 波モ デルによる反射損失 $L_{R}$ は、 
Table 4 Results of measurement-2

\begin{tabular}{|c|c|c|c|c|}
\hline & BER & $\begin{array}{c}\text { Detect } \\
\text { Rate }\end{array}$ & $\begin{array}{c}\mathrm{Eb} / \mathrm{No} \\
{[\mathrm{dB}]}\end{array}$ & $\begin{array}{c}\text { Pr } \\
{[\mathrm{dBm}]}\end{array}$ \\
\hline $\mathrm{A} 1023$ & $3.60^{*} 10^{-2}$ & 0.426 & 10.4 & -95.8 \\
\hline $\mathrm{N} 1023$ & $6.41^{*} 10^{-2}$ & - & 9.3 & -91.3 \\
\hline
\end{tabular}

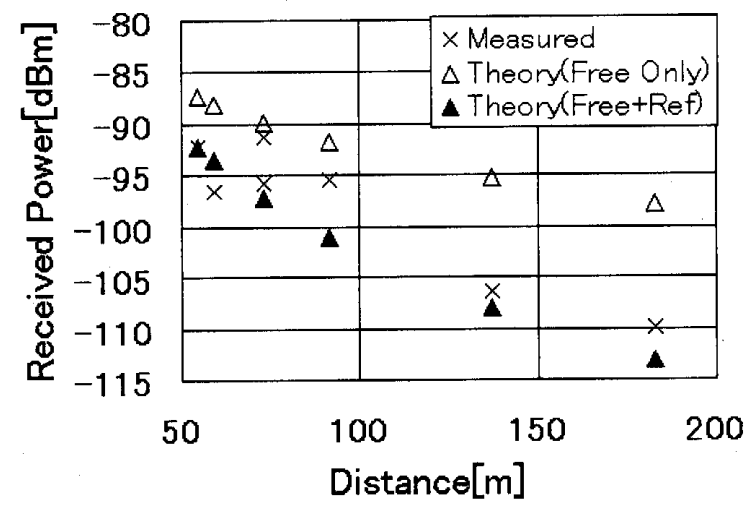

Fig.11 The characteristic of received power to the distance

$$
L_{R}=20 \log \left|2 \sin \left(\frac{2 \pi h_{1} h_{2}}{\lambda d}\right)\right|{ }^{\prime} \quad[\mathrm{dB}]
$$

である。ここで $h_{1} 、 h_{2}$ はそれぞれ送受信アンテナ高 さ、入は波長である。このとき伝搬損失 L は、

$L=L_{F}+L_{R} \quad[\mathrm{~dB}]$

であり、受信電力 $\mathrm{P}_{\mathrm{r}}$ の理論值は、

$P_{r}=P_{t}-L \quad[\mathrm{dBm}]$

で表される。Fig. 11 より、測定值は距離が $100 \mathrm{~m}$ 以 上になると反射損失を加えた伝搬損失 L に近い值と なっており、3.3 とは異なる結果を示した。これは 送信点が低い場合は直接波に対し反射波の影響が少 なく、逆に送信点が高くなると大きく影響すると考 えられるが、送信点の高さと受信電力の関係は今後 検討する必要がある。

今回の実験では受信側に指向性アンテナを使用し て約 $80 \mathrm{~m}$ で船陸間の微弱電波を用いた通信に成功し た。本実験で使用したモジュールは、通信速度は高 速だが受信感度は他の機器よりおおよそ $10 \mathrm{~dB}$ 程度 劣り、受信機の NF も大きい。そこで $\mathrm{RF}$ 部の最適化 を図り、また広帯域化により処理利得を増加すれば、 $30 \mathrm{~dB}$ 以上の利得増加が期待できる。例えば $20 \mathrm{~dB}$ 利 得が向上すれば、 $800 \mathrm{~m}$ 付近で今回の害験結果と同様
の BER が得られることになる。このように、今後の 性能改善により、位置情報システムの構築が可能と 考えられる。

\section{4. まとめ}

海上にお注簡易な位置情報通信システムの構筑 を目的として、GPS 受信機の時刻同期信号を利用し 拡散符号同期を簡易化した微弱電波 DS-SS 通信方式 の実現法を提案し、その通信特性について評価した。 市販の微弱無線モジュールを使用し、まず室内で DS-SS 方式によるBER 特性の改善効果を明らかにし、 本方式の有効性を示した。次にシステム実現のため の実証実験として屋外で同様に測定した結果、送受 信機閒距離 $80 \mathrm{~m}$ で $10^{-3}$ 以下の BER 特性が得られた。 最後に船陸間で同様の実験を行い、BER は若干低下 したものの、同程度の距離での通信に成功した。

また、位相検出系列を用いた場合の $\mathrm{Eb} / \mathrm{No}$ 特性は、 これを用いなかった場合よりも優れており、さらに 位相検出系列のコード長が長い方が良い $\mathrm{Eb} / \mathrm{No}$ 特性 が得られたことから、このチップ同期方法の改善は 有効であることがわかった。

これらの結果から、本方式を採用することにより、 市販の微弱電波機器でも通信品質の改善が可能であ ることを示した。今後 RF 部の改善等を行えば、通信 距離特性の向上も期待でき、本方式を利用した海上 位置情報通信システムなどへの応用が可能であると いえる。

一方、受信電力特性は送信点が低かった屋外実験 では自由空間伝搬特性で求められる理論值に近く、 高かった船陸間実験では反射の影響が大きくなった。 この受信電力及び通信距離の関係は今後検討を要す る課題である。他の課題としては、システムに適し た無線機器の開発、処理利得や伝送速度の性能向上、 測距性能の付加に対する検討などを行うことが挙げ られる。

\section{謝辞}

本研究を進めるにあたり、伝搬特性の理論值の計算 法など多くのご助言を戴きました日本無線株式会社 研究開発部基盤研究グループ木田弘幸担当部長に深 く謝意を表します。

\section{参考文献}

[1］郵政省,” 海上通信の高度化に関する研究会最 終報告,” pp. 16-20, p35-47, Dec. 2000.

[2] 中条渉, 手代木たすく, 三浦秀一, ”双方向搜索 
救難衛星通信システム,”信学技報, SANE84-26, 0ct. 1984.

[3] 和田雅昭, 天下井清, 木村暢夫, 岩森利弘, ”海中 転落者のための救助システムについて,” 日本航海 学会論文集, No. 108, pp. 181-188, Mar. 2003.

[4] 和田雅昭, 天下井清, 木村暢夫, 岩森利弘, 西澤直 晃, ”海中転落者のための救助システムについて 一, ”日本航海学会論文集No. 109, pp. 105-112, Sep. 2003.

[5] 和田雅昭, 天下井清, 木村暢夫, 岩森利弘, ”海中 転落者のための救助システムについて一,” 日本航 海学会論文集, No. 110, pp. 51-58, Mar. 2004.

[6] 和田雅昭, 天下井清, 木村暢夫, 岩森利弘, ”海中 転落者のための救助システムについてー, ” 日本航 海学会論文集, No. 111, pp. 165-172, Sep. 2004.

[7] 鈴木規夫, 丸岡嵩彌,”微弱電波を使ったデータ 伝送の技法, ”電波による無線デー夕伝送技術, ト ランジスタ技術編集部(編), pp. 6-15, 東京, 1996.

[8] 安藤裕武, 福島恵介, 羽田 寧, 岡野陽也, 鬼 沢正徳, “スペクトラム拡散方式の微弱電波による 無線データ伝送, " FUJITSU GENERAL TECHNICAL JOURNAL, 1999 No. 2, pp. 27-32, 1999.

［9］吉田将司, 北條晴正, 㚞春明, 安田明生, ” GPS の 時刻同期信号を利用した海上における位置情報通信 システムに関する研究, ” 日本航海学会論文集, No. 112, pp. 213-218, Mar. 2005.

[10] P. Misra, P. Enge (著) 日本航海学会GPS 研究会 (訳), 精説GPS 基本概念 - 測位原理 - 信号と受信機, 正陽文庫, 東京, 2004 .

[11] 森春明, 浪江宏宗, 古澤昌彦, 本多由希子, 安田 明生,”GPSによる時刻同期を用いた水中計測に関す る研究, ”日本航海学会論文集, No. 108, pp. 157-163, Mar. 2003.

[12］Behzad Razavi著, 黒田忠広監訳, RFマイクロエ レクトロニクス, pp. 81, 丸善株式会社, 2002.

[13]，野本真一, ワイヤレス基礎理論, pp. 321, 電子情 報通信学会, 2003.

[14] 横山光雄, スペクトル拡散通信システム, pp. 467 , 科学技術出版, 2002. 